\title{
Wind farm construction impacts reindeer migration and movement corridors
}

\author{
Anna Skarin (1) C Christian Nellemann • Lars Rönnegård • \\ Per Sandström • Henrik Lundqvist
}

Received: 28 October 2014 / Accepted: 8 May 2015/Published online: 15 May 2015

(C) The Author(s) 2015. This article is published with open access at Springerlink.com

\begin{abstract}
Context Over the last decade, we have seen a massive increase in the construction of wind farms in northern Fennoscandia. Wind farms comprising hundreds of wind turbines are being built, with little knowledge of the possible cumulative adverse effects on the habitat use and migration of semi-domesticated free-ranging reindeer.

Objectives We assessed how reindeer responded to wind farm construction in an already fragmented landscape, with specific reference to the effects on use of movement corridors and reindeer habitat selection. Methods We used GPS-data from reindeer during calving and post-calving in the Malå reindeer herding community in Sweden. We analysed data from the pre-development years compared to the construction years of two relatively small wind farms.

Results During construction of the wind farms, use of original migration routes and movement corridors
\end{abstract}

A. Skarin $(\bowtie) \cdot$ H. Lundqvist

Department of Animal Nutrition and Management,

Swedish University of Agricultural Sciences,

P.O. Box 7024, 75007 Uppsala, Sweden

e-mail: anna.skarin@slu.se

H. Lundqvist

e-mail: h.lundqvist@gmail.com

C. Nellemann

United Nations Environment Programme, GRID Arendal,

Fakkelgården, Storhove, 2624 Lillehammer,

Norway

e-mail: christian.nellemann@grida.no within $2 \mathrm{~km}$ of development declined by $76 \%$. This decline in use corresponded to an increase in activity of the reindeer measured by increased step lengths within $0-5 \mathrm{~km}$. The step length was highest nearest the development and declining with distance, as animals moved towards migration corridors and turned around or were observed in holding patterns while not crossing. During construction, reindeer avoided the wind farms at both regional and landscape scale of selection.

Conclusions The combined construction activities associated with even a few wind turbines combined with power lines and roads in or close to central movement corridors caused a reduction in the use of such corridors and grazing habitat and increased the fragmentation of the reindeer calving ranges.

Keywords Rangifer - Disturbance $\cdot$ Anthropogenic development $\cdot$ Step length · GPS collars · Cumulative effects

\section{Rönnegård}

Section of Statistics, School of Technology and Business Studies, Dalarna University, 79188 Falun, Sweden e-mail: lrn@du.se

\section{P. Sandström}

Department of Forest Resource Management, Swedish University of Agricultural Sciences, 90183 Umeå,

Sweden

e-mail: per.sandstrom@slu.se

H. Lundqvist

County board of Jönköping County, Jönköping, Sweden 


\section{Introduction}

Reindeer husbandry is one of the major livelihoods of Sámi people in Fennoscandia and of major importance to Sámi culture. The reindeer (Rangifer tarandus tarandus) are herded in a pastoral system, where the animals move freely in the landscape during most of the year, often making extensive migrations between seasonal ranges to make use of the natural forage resources. One of the major threats to current Sámi reindeer husbandry is habitat loss due to direct or indirect impacts from competing land use (Danell 2005; Pape and Loeffler 2012). Numerous studies have documented large-scale effects on free-ranging reindeer from industrial development, resorts, roads, power lines and forestry operations, especially during late winter and the calving season (for review see Skarin and Åhman 2014). Forestry, along with fragmentation from infrastructure such as roads, power lines, mines, industrial construction sites and population centres, prevents reindeer from selecting optimal grazing land and using their available forage resources effectively (e.g. Anttonen et al. 2011; Helle et al. 2012).

Over the last decade, we have seen a massive increase in the planning and construction of wind farms in Northern Europe. For example, in Sweden, the goal is to increase energy production from wind from 7 TWh per year at present to 30 TWh in 2020, representing a total of 3000-5000 wind turbines (Riksdagen 2009). With such a scale of development, involving construction periods extending over several years, an increased knowledge of the cumulative impacts is critical in order to mitigate those impacts from work already in the planning phase. Wind "farms" containing several hundred and even one thousand wind turbines are being planned and built, with little knowledge of the possible adverse effects on reindeer husbandry and the habitat use and migrations of free-ranging reindeer, as well as other species. Until now, only two studies have examined the effect of wind farm construction sites and only at very local scales (Colman et al. 2012, 2013), thus possibly seriously underestimating the regional avoidance that is clearly the most commonly observed impact on reindeer and caribou of industrial development; this has been widely observed in more than 48 studies in the circumpolar Arctic (Vistnes and Nellemann 2008; Skarin and Åhman 2014). Pre- and post-development studies are particularly important at broader scales in order to detect any changes in use by reindeer, with studies showing reduced use up to tens of kilometres, even over decades (Nellemann et al. 2001, 2003, 2010). Furthermore, effects during the period of turbine construction on reindeer in a managed forested landscape at multiple scales and during the sensitive calving period have received little attention, and possible effects on movement corridors remain entirely unknown.

In general, migrating animals select the migration routes and movement corridors of least resistance, following natural terrain and being funnelled into routes where movement is considered the safest and energetically economic (Sawyer et al. 2009; Panzacchi et al. 2012). The disruption of migration routes as a result of human activities and infrastructure has been observed for decades amongst reindeer herders (Klein 1971; Vistnes and Nellemann 2001; Össbo and Lantto 2011; Pape and Loeffler 2012), however it has not previously been quantified scientifically with respect to free-ranging reindeer. The effects of reindeer on additional development in already fragmented landscapes are important to understand in order to address fully the impacts of progressive development (Nellemann et al. 2003; Joly et al. 2006).

The aim of this study was to assess how freeranging reindeer responded to wind farm construction in an already fragmented landscape with specific reference to the effects on both use of movement corridors and habitat selection at different scales. We used data from GPS equipped reindeer supported by information from Sámi reindeer herders to identify reindeer movement corridors. Within these corridors we compared reindeer step length and amount of stop over habitat before and during construction close to and far away from the wind farm, to assess whether the reindeer increased their activity and decreased their use, respectively, in these corridors as a response to being frightened by the construction activity of the wind farm. We used resource selection functions (RSFs) to evaluate reindeer habitat selection in relation to the wind farm construction site, habitat types, topography, water, and existing infrastructure (roads and power lines) before and during construction, following Johnson's (1980) second- and thirdorder selection to assess whether reindeer avoid the wind farm area during construction. 


\section{Method}

Study area

The study area is situated in and around the two wind farms at Storliden mountain (eight wind turbines being constructed in 2010-2011) and at Jokkmokksliden mountain (ten wind turbines being constructed in 2010-2011), located in the calving and post-calving ranges of the Malå forest reindeer herding community. The range used by the reindeer varies between years, it amounts to $870 \mathrm{~km}^{2}$ (excluding lakes), and is approximately $30 \%$ of the entire range used during the snow-free period in the community (Fig. 1). The study area was used by approximately 1200 female reindeer and their calves (the total number of reindeer in the community is 6200 in the winter herd; pers. com. J Rannerud, head of Malå reindeer herding community). It is characterised by undulating forest interspersed with mires, lakes and hills or smaller mountains, with forested land comprising old growth forest, clear cuts and plantations. The calving area is generally considered by the herders to consist of three separate grazing areas for the reindeer as a result of human activity and roads, with specific migration routes or connecting corridors (pers. com. Rannerud; Sametinget 2015). An eastern and a western portion are separated by a public north-south spine road running from the town of Malå to the north, connecting several smaller settlements. The relatively steep mountain slopes of Jokkmokksliden and the hills east of Jokkmokksliden create naturally narrow movement corridors between reindeer foraging areas to the east and the west of the road and the hills. The eastern portion is then, in turn, separated into one northern and one southern part by a main road running from east to west without settlements, and also by a separate $30 \mathrm{kV}$ power line further north stretching from the east to the west through the whole study area, but the latter is not associated with any human movement (Fig. 1). The

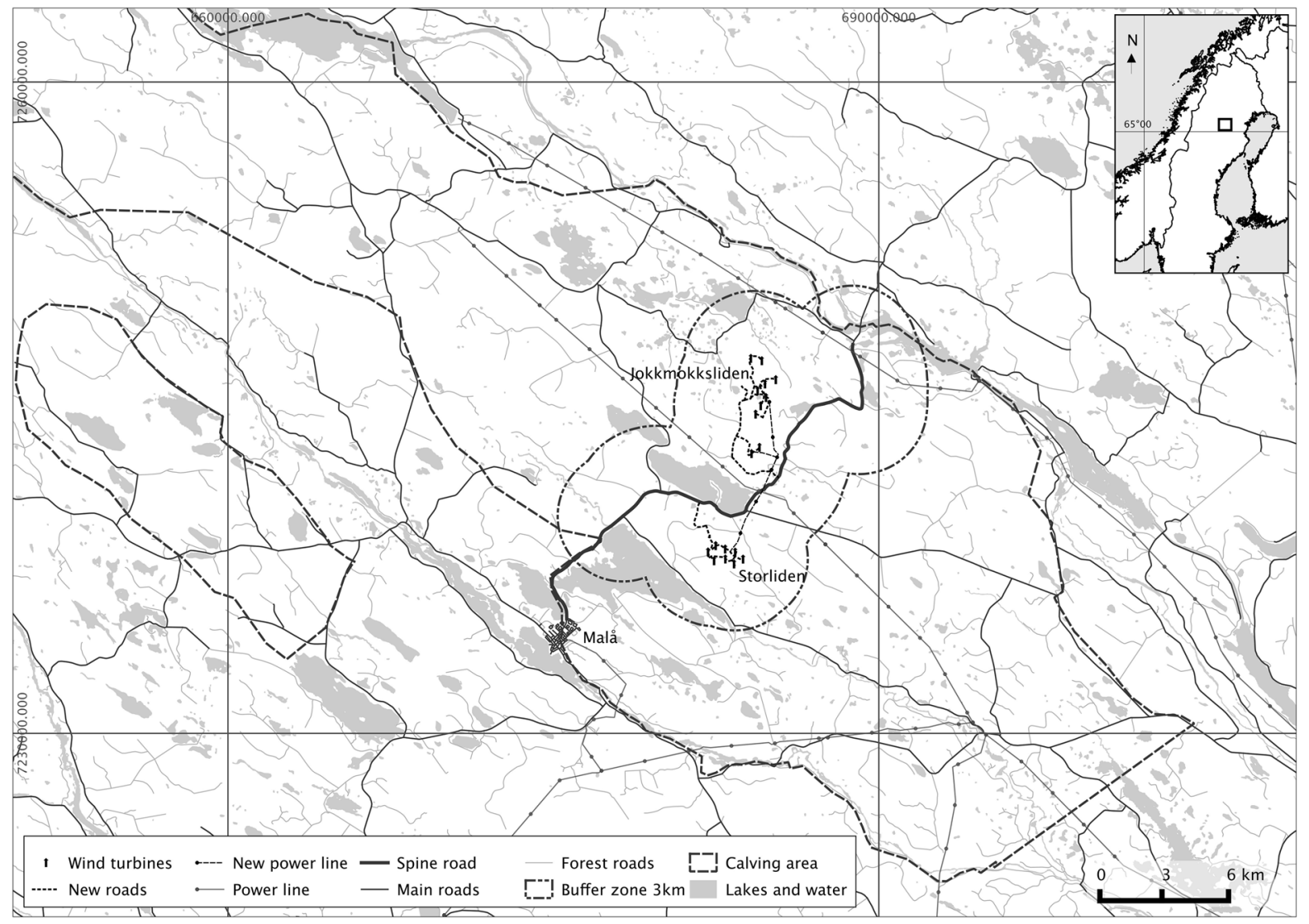

Fig. 1 Map of the Malå reindeer herding community's calving and post-calving area. SWEREF99 TM (ESPG:3006) projected coordinates. (C) Lantmäteriet, i2014/764 
forest at Jokkmokksliden is intensively managed and contains a high proportion of Pinus contorta plantations $(20 \%)$ and dense young forest (30\%), giving little ground vegetation cover. Forest with trees $<5 \mathrm{~m}$ is classified as young forest, and open areas with trees $<2 \mathrm{~m}$ are classified as clear cuts (Reese et al. 2003). At Storliden there are areas of old growth forest, plantations of $P$. contorta (14\%), young forest (20\%), and clear cuts (14\%). According to the herders, the reindeer prefer Storliden just after calving (pers. com. J. Rannerud). Apart from the forest harvest on behalf of the wind farm, there were no harvesting actions in the study area during our study period.

GPS data collection

A total of 80 female reindeer cows have been fitted with GPS collars since 2007 (Followit Lindesberg AB, reindeer collar). As we studied the use of a calving range adult females were chosen as study animals. Furthermore, females also make up the majority (ca. $70 \%$ ) of the herd, and they normally move as part of a herd except for about 1 week after individual calving, and are thus likely to provide the most representative picture of how the reindeer herds use their ranges (Skarin and Ahman 2014). We used position data collected every $2 \mathrm{~h}$ from female reindeer that occupied the study area in and around the construction site during the calving and post-calving seasons in 2008-2011 (Table 1). The start of the calving season was defined as occurring after the arrival of the reindeer in the study area following spring migration from the winter grounds; the season ends a period of free ranging with the reindeer herders starting to gather the reindeer for calf marking. The exact dates of the start and the end of the season differed between the four study years. Fix success of the GPS collars was sometimes low, $\sim 1 \%$ of the positions were removed having high DOP-value $(>10)$ and 2D positioning (Frair et al. 2010). The data was downloaded from the collars via the global system for mobile communications (GSM) cell phone network, at some occasions the reindeer used areas with low GSM-coverage not making data download possible. Thus, we excluded reindeer with more than $15 \%$ of their positions missing due to holes in the data. In total we used 23,205 locations from 5 to 15 individual reindeer recorded each year in our analysis (Table 1).

Habitat variables

Variables assembled to explain reindeer habitat selection in the RSF-models were vegetation type, forest height, elevation, ruggedness, slope, and minimum distance to road, power lines and new infrastructure within the wind farm area. All variables were screened for collinearity using the Variance inflation factors (VIF; Zuur et al. 2009), and we used VIF $\geq 3.0$ as a threshold for removing a variable. Furthermore, pairwise correlation was also checked for using Pearson's correlation coefficient between the variables, and we used $r \geq 0.5$ as the threshold for removing one of the variables. All environmental parameters (Table 2) were first extracted using Arc GIS 9.3 ${ }^{\mathrm{TM}}$ software (ESRI Inc., (C) 1999-2009). All the digitized geographical data, except the forest height structure (Swedish kNN-layer; ftp://salix.slu.se/down load/skogskarta/), were provided by Lantmäteriet (http://www.lantmateriet.se), which supplies national geographic and land information data. The $k \mathrm{NN}$ height

Table 1 Study phases in the Malå study area in northern Sweden, over the four study years with number of days and number of reindeer fitted with devices providing a GPS position every $2 \mathrm{~h}$

\begin{tabular}{|c|c|c|c|c|c|c|c|}
\hline \multirow[t]{2}{*}{ Phase } & \multirow[t]{2}{*}{ Year } & \multirow[t]{2}{*}{ Date } & \multirow[t]{2}{*}{ Days } & \multirow[t]{2}{*}{$\begin{array}{l}\text { No. of } \\
\text { crossings }\end{array}$} & \multicolumn{3}{|c|}{$\begin{array}{l}\text { Number of reindeer within the buffer } \\
\text { zones around the wind farm area }\end{array}$} \\
\hline & & & & & $2 \mathrm{~km}$ & $4 \mathrm{~km}$ & $6 \mathrm{~km}$ \\
\hline Pre-construction & 2008 & $12 / 5-18 / 6$ & 37 & $57(11)$ & 14 & 15 & 15 \\
\hline Pre-construction & 2009 & $2 / 5-19 / 6$ & 49 & $9(3)$ & 6 & 10 & 11 \\
\hline Construction & 2010 & $10 / 5-24 / 6$ & 46 & $12(4)$ & 13 & 14 & 14 \\
\hline Construction & 2011 & $10 / 5-22 / 6$ & 44 & 0 & 3 & 5 & 5 \\
\hline
\end{tabular}

Numbers of crossings represent each event of a GPS-reindeer crossing over the spine road and/or the wind farm site, and in parentheses the number of reindeer individuals 
Table 2 Proportion, densities or ranges (median value in parentheses) of environmental parameters $(50 \mathrm{~m}$ resolution) within the Malå study area

Range or percentage in whole study area

\begin{tabular}{|c|c|}
\hline \multicolumn{2}{|l|}{ Vegetation type classes } \\
\hline Barren ground & 0.97 \\
\hline Heath & 1.2 \\
\hline Broadleaved forest & 0.7 \\
\hline $\begin{array}{l}\text { Coniferous forest }(>5 \mathrm{~m} \\
\text { stem length) }\end{array}$ & 34.0 \\
\hline Mixed forest & 3.1 \\
\hline $\begin{array}{l}\text { Clear cuts }(<2 \mathrm{~m} \\
\text { stem length })\end{array}$ & 12.3 \\
\hline $\begin{array}{l}\text { Young forest }(<5 \mathrm{~m} \\
\text { stem length) }\end{array}$ & 19.7 \\
\hline Mires & 28.1 \\
\hline \multicolumn{2}{|l|}{ Continuous variables } \\
\hline Elevation & $236-562(356) \mathrm{m}$ \\
\hline Slope (degrees) & $0-34(1.3)$ \\
\hline Ruggedness index & $0-0.04(0.0001)$ \\
\hline Forest height & $0-19(6) \mathrm{m}$ \\
\hline $\begin{array}{l}\text { Main road density }>5 \mathrm{~m} \text { (including } \\
\text { the spine road) and distance range }\end{array}$ & $\begin{array}{l}0-6.0 \mathrm{~km} / \mathrm{km}^{2}(0.0) \\
0-4365 \mathrm{~m}(939)\end{array}$ \\
\hline $\begin{array}{l}\text { Forest road density }<5 \mathrm{~m} \text { and } \\
\text { distance range }\end{array}$ & $\begin{array}{l}0-1.82 \mathrm{~km} / \mathrm{km}^{2}(0.48) \\
0-2487 \mathrm{~m}(447)\end{array}$ \\
\hline Power line density and distance range & $\begin{array}{l}0-1.26 \mathrm{~km} / \mathrm{km}^{2}(0.0) \\
0-12,847 \mathrm{~m} \mathrm{(3218)}\end{array}$ \\
\hline $\begin{array}{l}\text { Density of wind farm construction } \\
\text { site (new power lines and roads) } \\
\text { and distance range }\end{array}$ & $\begin{array}{l}0-2.47 \mathrm{~km} / \mathrm{km}^{2}(0.0) \\
0-21,552 \mathrm{~m}(8663)\end{array}$ \\
\hline Distance to nearest water & $0-1632 \mathrm{~m}(212)$ \\
\hline
\end{tabular}

Total size of the study area is $870 \mathrm{~km}^{2}$, excluding lakes

data were derived from a combination of satellite imagery, field data and algorithms that validate and determine $k$-Nearest Neighbour $(k \mathrm{NN})$ distances (Reese et al. 2003). There are 43 vegetation classes from the Swedish Landcover Map present in the area (SMD, Lantmäteriet 2004). We complemented the SMD layer, which originates from satellite images from the year 2000, with satellite data for each study year to include changes from old forest to clear-cuts and clear-cuts to young forest. The 43 classes were then combined into eight classes (Table 2). The class variables were resampled from the $25 \mathrm{~m}$ grid to a $50 \mathrm{~m}$ grid, where the most common class from the $25 \mathrm{~m}$ grid determined the new class of the $50 \mathrm{~m}$ grid. The digital elevation model layer provided had a resolution of
$50 \mathrm{~m}$ and a vertical accuracy of $\pm 2 \mathrm{~m}$. The ruggedness index was calculated as described by Sappington et al. (2007) with a $5 \times 5$ neighbourhood using the SAGA GIS (http://www.saga-gis.org) module.

Wind farm construction site and existing infrastructure

The years 2008 and 2009 were defined as predevelopment years (hereafter referred to as the "preconstruction" phase), during which the area had existing infrastructure such as a road network, power lines and an underground mine on the north side of Storliden. In total, there were $265 \mathrm{~km}$ of main road network and $69 \mathrm{~km}$ of power lines in our main study area. In spring 2010, the construction and establishment of the two wind farms started in the hills along the spine road. To access the wind farms, $22 \mathrm{~km}$ of new roads were constructed, with $8.5 \mathrm{~km}$ of $36 \mathrm{kV}$ power lines connecting to the existing power grid via the new utility station built in between the wind farms. At Jokkmokksliden, the full infrastructure was developed in 2010 and the first five wind turbines were constructed, with another five turbines being erected in 2011. At Storliden, the road network and power lines were established in 2010 and the turbines were put in place in 2011, starting to generate electricity in November 2011. The years 2010 and 2011 are hereafter referred to as the "construction" phase, as development continued throughout. In addition, to deliver the energy produced by the wind farm, the $30 \mathrm{kV}$ power line stretching through the whole study area from east to the west was enlarged to a $145 \mathrm{kV}$ power line during the 2010/2011 winter season when reindeer were absent from the area. All the Euclidian distances of the linear features, such as roads and power lines, were calculated using ArcGIS.

\section{Detecting changes in use of movement corridors}

To identify potential changes in the use of the area around the wind farm construction sites, we counted the number of crossings of the wind farm area and over the spine road by the GPS-tracked reindeer. Furthermore, we calculated the step length [distance between two GPS relocations $(\mathrm{m} / 2 \mathrm{~h})$ ] of the individual reindeer. We then tested the step-length before and during construction in a classical difference in difference (DID) setup (Angrist and Pischke 2009). The step 
length in the pre-construction phase was compared with the step length in the construction phase within 1 , 2, 3, 4, 5 and $6 \mathrm{~km}$ buffer zones around the wind farm area (Sawyer et al. 2013). Thus, we estimated the effect close to the wind farm construction sites and used the surrounding area further away as control in two time periods. We used a standard two-sample $t$ test to determine whether movement rates varied between the two periods and within which distance (buffer zone) a probable difference between pre-construction and construction no longer existed. The buffer distances were arbitrary chosen; however covering distances from the wind farm, which we know from the disturbance literature could have an effect on reindeer (Skarin and Åhman 2014).

Secondly, we used the Brownian Bridge Movement Model (BBMM) to estimate individual- and population-level movement corridors for GPS-collared reindeer for each study phase (Horne et al. 2007). Compared to the ordinary kernel home range estimation or minimum convex polygon (MCP), which both combine locations dependent on distance, the BBMM methodology provides a unique opportunity to identify reindeer movement and migration patterns as it is dependent on both time and distance between the locations (Horne et al. 2007; Sawyer et al. 2013). If a reindeer did not appear within $6 \mathrm{~km}$ of the wind farm area (Fig. 1) it was excluded from the movement corridor analysis during that season (Table 1). We estimated the utilisation distribution (UD) of an animal using a Brownian bridge kernel method (Calenge 2006; Horne et al. 2007). This method places a smoothing (kernel) function above each line connecting two successive GPS locations. The smoothing function is a combination of two bivariate normal density functions and a Brownian bridge density function connecting the two points (Horne et al. 2007). The $R$ ( $R$ Core Team 2015) package "adehabitatHR" (Calenge 2006) was used for the analysis. The spatial extent of the UD was defined as the $99 \%$ BBMM home range boundary and was displayed on a $50 \mathrm{~m}$ grid. We used an estimated location error of $20 \mathrm{~m}$. The resolution chosen corresponded to the lowest resolution of the habitat variables used. Population-level movement corridors within each season were then estimated by averaging the individual UDs within each study phase (Sawyer et al. 2013). The UD at both individual and population level provides a probabilistic measure of the movement corridors, whilst the height of the UD reflects intensity of use and the contours of the UD represent the surface area of the corridors.

The change in the intensity of use was evaluated by determining change in use of "stopover" habitats (Sawyer et al. 2009) or high-use areas within the development area, as we treated the step length with a DID setup. Stopover habitats were defined as the highest $25 \%$ quartile in the UD. At the individual level, we calculated the area of stopover habitat for each reindeer within each study phase within the 1,2 , $3,4,5$ and $6 \mathrm{~km}$ buffer zones. We used a standard twosample $t$ test to determine whether there was a difference in the area amount of stopover habitats between pre-construction and construction phases for each of the buffer zones.

\section{Habitat selection}

RSFs provide a tool to estimate animal preference for, or avoidance of, certain habitats and linear structures such as roads and power lines, at multiple scales (Johnson 1980; Manly et al. 2002; Polfus et al. 2011). We developed RSF-models with a use-availability design (Manly et al. 2002) to evaluate whether the wind farm construction phase affected the reindeer habitat selection. To assess the habitat selection at landscape scale and the home range scale we developed the RSF-models within Johnson's (1980) second-order (landscape, home range placement) selection and third-order (within home range) selection, respectively. We compared habitat variables at reindeer GPS locations to random available locations within the calving/post-calving range defined by the MCPs (computed from $95 \%$ of all GPS-positions to exclude outliers), to assess the second-order selection. To assess the third-order selection we compared habitat variables at reindeer GPS locations to random available locations within the individual BBMM home ranges. Only data from collars that, at some point, were recorded within the $2 \mathrm{~km}$ buffer zone around the wind farm were included in the RSF-analysis since it was the change in use around the wind farm we wanted to investigate. To assess if there was avoidance of the wind farm area during the construction phase, the locations were split between pre-construction and construction phases, allowing an interaction between GPS-locations distances to the wind farm within each phase to be incorporated into the model. We generated 
available points using a 1:1 ratio of used to available locations. Habitat selection was evaluated using generalized linear mixed-models with each individual animal per year as a random factor to account for sample size and autocorrelation (Gillies et al. 2006). The R-package "Ime4" (Bates et al. 2014) was used for the analysis. AIC-values were used to identify the most parsimonious model in the selection of prediction parameters. To validate the models with the best fit, we used a k-fold cross validation (Boyce et al. 2002). A training set of data was extracted and used to calculate a Spearman's rank correlation between the observed positions therein and the predicted probability of selecting those positions using the model. The predicted probability was arbitrarily divided in ten equal bins. A testing ratio of $20 \%$ was determined and a k-fold partition of five groups was used. This resulted in five correlations to evaluate the model fit.

\section{Results}

Detecting changes in use of movement corridors

During the study period, we identified 66 crossings by 14 (out of 26) reindeer through the wind farm area and across the spine road during the pre-construction phase, but only 12 crossings by 4 (out of 19) during the construction phase. This corresponds to 0.030 crossings/reindeer and day (54\% of reindeer crossings) compared to 0.007 crossings/reindeer and day $(21 \%$ of reindeer) during the construction phase, corresponding to a $76 \%$ relative decline in crossings following development. Hence, a clear change took place during the construction phase. Before the calving season started, the reindeer moved into the calving area east of the construction site, arriving from the south and the west to stay in the area during calving. During the post-calving period, they either stayed in the same area or they moved out of the area, mainly to the west but also to the south-western part of the grazing range. This traffic substantially declined following development.

\section{Step-length analysis}

The mean reindeer step lengths over all study years were $326 \pm 2.73 \mathrm{~m} / 2 \mathrm{~h} \quad( \pm \mathrm{SE})$. Comparing step lengths during calving in the pre-construction and construction phases, we also found support for the hypothesis that construction impacted reindeer movement. We found a significant increase in step length in all zones $<5 \mathrm{~km}$ from the wind farms during construction phase (within the $5 \mathrm{~km}$ buffer zone: step length increased from $302 \pm 5.5$ to $326 \pm 6.3(\mathrm{t}=$ $-2.90, \mathrm{P}=0.004)$; Fig. 2a). At $6 \mathrm{~km}$ the difference seemed to decrease $(\mathrm{t}=-1.95, \mathrm{P}=0.051)$. No significant differences were found when comparing step lengths outside the $5 \mathrm{~km}$ buffer zone before and during construction $(\mathrm{t}=-0.94, \mathrm{P}=0.345)$.

Change in stopover area and total BBMM surface within the wind farm area

Following development in the construction phase, reindeer gathered in apparent holding patterns on either side of their former migration routes or movement corridors - with minimal crossing (Fig. 3). This was also reflected in a significant decrease in the amount of individual stopover habitat within the $1 \mathrm{~km}$ $(\mathrm{t}=2.33, \mathrm{P}=0.044), 2 \mathrm{~km}(\mathrm{t}=3.75, \mathrm{P}=0.001)$ and $3 \mathrm{~km}(\mathrm{t}=2.25, \mathrm{P}=0.035)$ buffer zones during the construction phase compared to the pre-construction phase, while no such significant difference was observed within the individual 4, 5 and $6 \mathrm{~km}$ buffer zones. For areas beyond the $5 \mathrm{~km}$ buffer zone there was no significant difference $(\mathrm{t}=-0.69, \mathrm{P}=0.497$; Fig. 2b). Furthermore, there was not any significant difference in mean amount of stopover habitat within the whole study area before or during development, i.e. the total amount of stop over habitats remained unchanged between before and during development but the spatial distribution of the stop over habitat within the study area changed.

\section{Habitat selection}

Among the habitat variables, the VIF did not indicate any apparent multicollinearity, while moderate pairwise correlations were detected. The Pearson pairwise correlation exceeded 0.5 between elevation and distance to all the new infrastructure, slope and ruggedness, and forest height and vegetation type. Thus, evaluating the best model we included only one member of each of these pairs of parameters when selecting the most parsimonious model. Parameters identified in the most parsimonious models were 
(a)

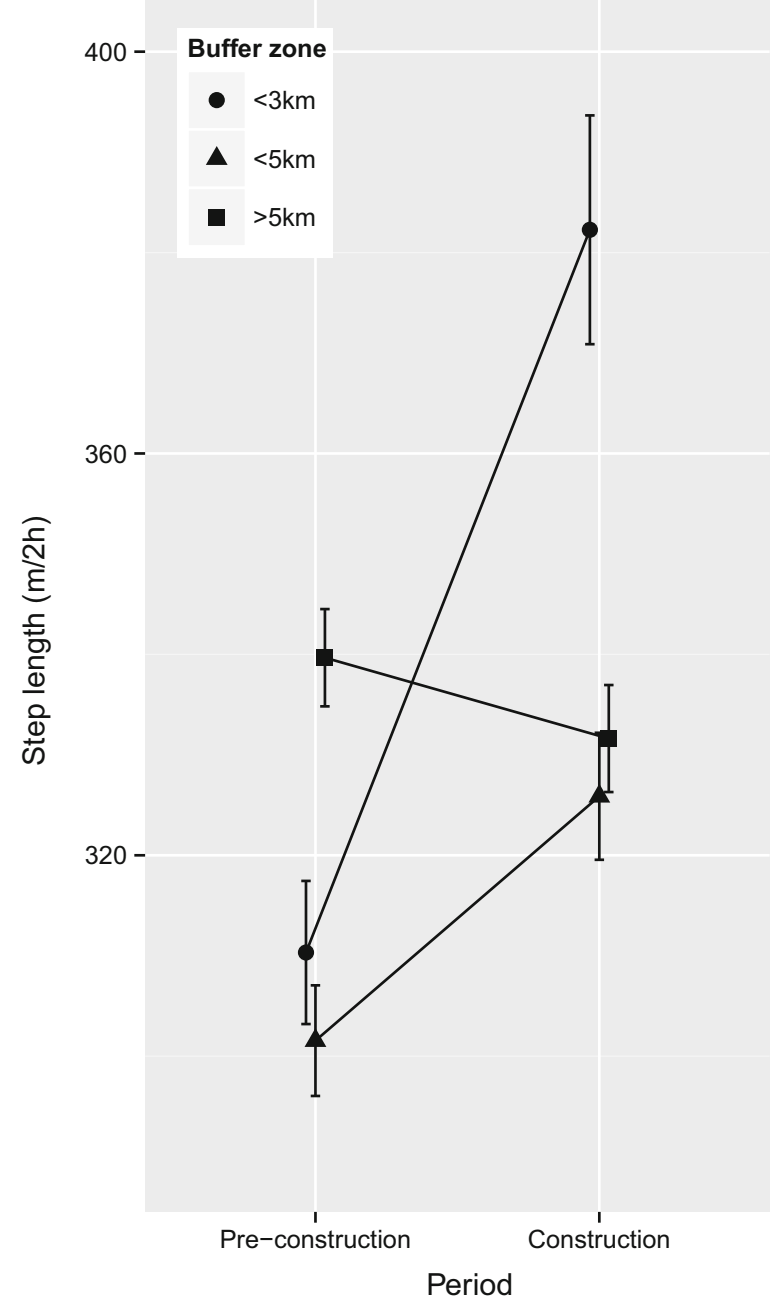

Fig. 2 a Difference in mean step length $(m / 2 h \pm S E)$ in the pre-construction and constriction phases within 3 and $5 \mathrm{~km}$ of the wind farm area and the mean step lengths for all reindeer outside the $5 \mathrm{~km}$ buffer zone. b Amount of mean individual

vegetation type, slope, distance to water, distance to large road, distance to small road (only included in the model estimating the third-order selection), distance to wind farm in interaction with study phase, (for all distance variables we used the square root of the distance, apart from distance to water where the logarithm of the distance was used, as this gave distributions closest to normal distribution) (Table 2). The results of the RSF-models (Table 3) showed that, at both the second-order scale (landscape i.e. selection of home range placement) and the third-order scale (i.e. within the BBMM home range), reindeer (b)

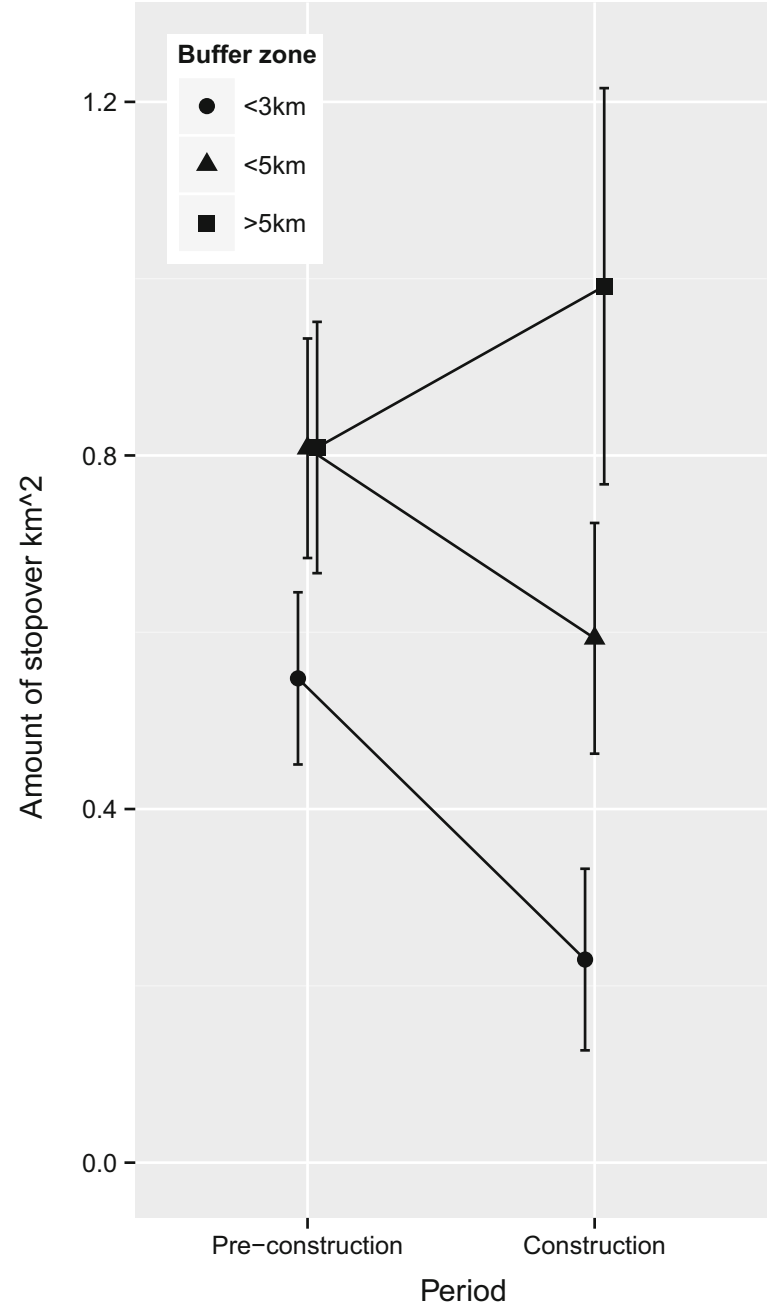

stopover habitat $\left(\mathrm{km}^{2}\right.$, upper $25 \%$ quartile of the UD) within 3 and $5 \mathrm{~km}$ of the wind farm area during the pre-construction phase compared to the construction phase, and mean stop over habitat outside the $5 \mathrm{~km}$ buffer zone

preferred the wind farm area during the pre-construction phase and that this preference turned into an avoidance of the wind farm area during the construction phase. Large roads were also avoided at both scales if considered, while the power lines were preferred. Moreover, open habitats like heaths and clear cuts were preferred. At the third-order scale, the reindeer also selected for small roads possibly reflecting avoidance of insects during the post-calving period. Hence, the reindeer home ranges seemed to be placed closer to the wind farm area in the preconstruction phase than during the construction phase. 

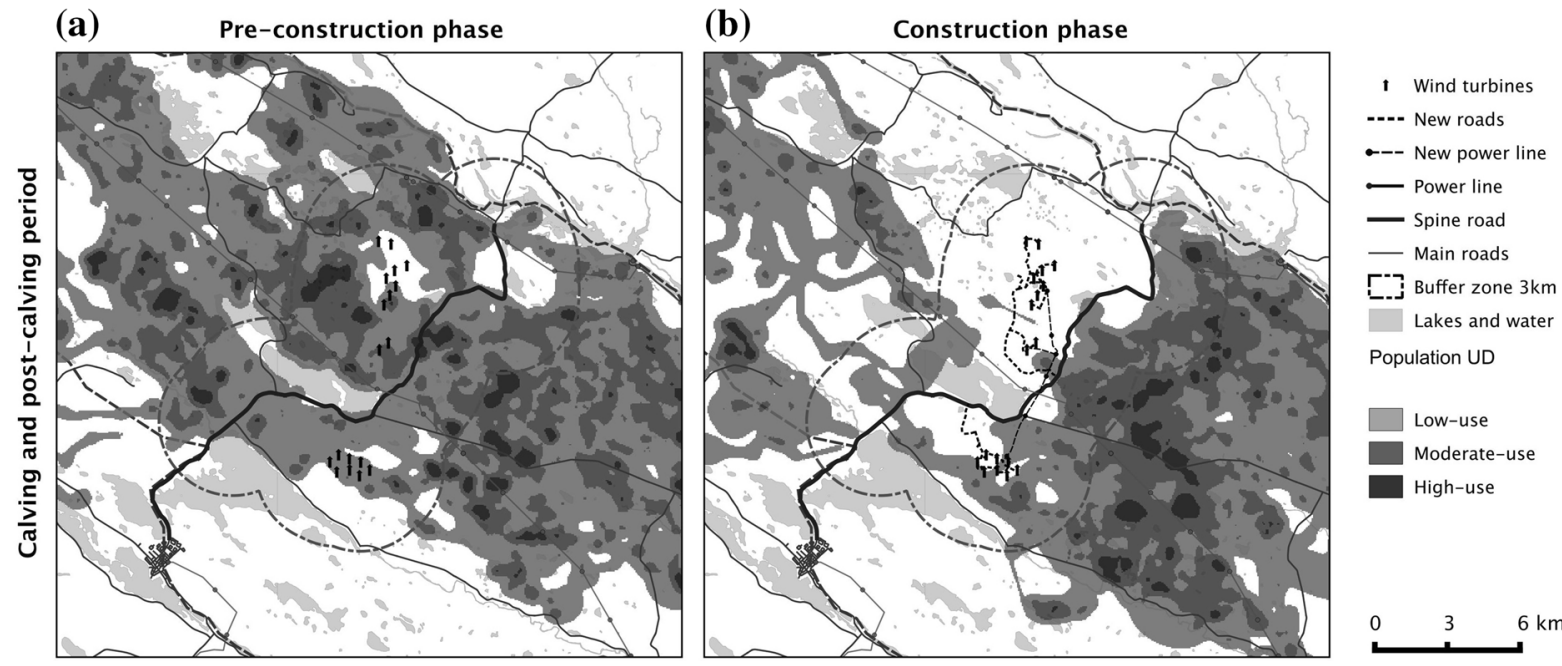

Fig. 3 Estimated reindeer population UD Brownian Bridge Movement Models, in the wind farm construction area during the preconstruction phase (a) and the construction phase (b) within the calving and post-calving period. (C) Lantmäteriet, i2014/764

Table 3 Regression estimates from the most parsimonious RSF-models for female reindeer second-order and third-order selection in and around the wind farm construction site during the pre-construction phase and the construction phase in Malå reindeer-herding community, Sweden

\begin{tabular}{|c|c|c|c|c|c|c|}
\hline \multirow[t]{2}{*}{ Calving } & \multicolumn{3}{|c|}{ Second-order } & \multicolumn{3}{|c|}{ Third-order } \\
\hline & Estimate & SE & $\operatorname{Pr}(>|z|)^{\mathrm{a}}$ & Estimate & SE & $\operatorname{Pr}(>|z|)^{\mathrm{a}}$ \\
\hline Barren ground & -0.271 & 0.157 & 0.083 & 0.728 & 0.201 & 0.000 \\
\hline Heath & 1.427 & 0.101 & 0.000 & 1.227 & 0.102 & 0.000 \\
\hline Broad leaved forest & 0.267 & 0.165 & 0.106 & -0.077 & 0.155 & 0.617 \\
\hline Coniferous forest & -0.130 & 0.067 & 0.051 & -0.007 & 0.075 & 0.923 \\
\hline Mixed forest & -0.370 & 0.096 & 0.000 & -0.436 & 0.101 & 0.000 \\
\hline Clear cuts & 0.757 & 0.069 & 0.000 & 0.924 & 0.076 & 0.000 \\
\hline Young forest & 0.080 & 0.067 & 0.232 & 0.150 & 0.075 & 0.044 \\
\hline Mires & 0.167 & 0.064 & 0.009 & 0.110 & 0.074 & 0.138 \\
\hline Slope (degrees) & -0.106 & 0.006 & 0.000 & -0.030 & 0.007 & 0.000 \\
\hline Distance to water $(\log )$ & 0.056 & 0.008 & 0.000 & -0.007 & 0.002 & 0.000 \\
\hline Distance to power lines (sqrt) & -0.003 & 0.001 & 0.000 & -0.005 & 0.001 & 0.000 \\
\hline Distance to large road (sqrt) & 0.017 & 0.001 & 0.000 & 0.008 & 0.001 & 0.000 \\
\hline Distance to small road (sqrt) ${ }^{\mathrm{b}}$ & - & - & - & -0.004 & 0.001 & 0.001 \\
\hline Distance to wind park (sqrt) & -0.009 & 0.001 & 0.000 & -0.002 & 0.001 & 0.002 \\
\hline Distance to wind park (sqrt): construction phase & 0.001 & 0.001 & 0.003 & 0.003 & 0.001 & 0.000 \\
\hline
\end{tabular}

${ }^{\mathrm{a}} \mathrm{P}=0.000$ equal to $\mathrm{P}<0.001$

b The variable distance to small roads was only included in the model estimating the third-order selection

Within the home ranges, reindeer spent considerable time near smaller roads intersecting the entire study area and the single remote $30 \mathrm{kV}$ power line, but avoided the spine road and during construction phase also the wind farm areas, thus choosing to use areas with the least potential relative disturbance, which also provided open habitats.

The mean Spearman rank for the k-fold cross validation at the second-order selection scale was $r=0.99(\mathrm{P}<0.001)$ for the most parsimonious 
models found for the calving season. At the third-order scale the cross validation was $r=0.57(\mathrm{P}=0.087)$. The low k-fold cross validation value for the thirdorder selection could be explained by a limited spatial spread of used and available locations within the individual home ranges, i.e. low variation, in the RSFmodel making the fitted model less general with a lower cross validation value as a result.

\section{Discussion}

The construction phase of the wind farms and existing infrastructure had a clear impact on reindeer migration, movement rate and habitat selection during the calving season. First, reindeer's use of movement corridors almost ceased during development and the reindeer step length increased significantly within $5 \mathrm{~km}$ of the wind farm during development. This was apparently an effect of development, as seen by activity patterns. Indeed, step lengths increased significantly at short distances, but not at greater distances from the wind farm areas and associated infrastructure. Second, the reindeer habitat use and selection was altered during the construction phase. Reindeer decreased their use of stopover habitat within $3 \mathrm{~km}$ of the wind farms during development, while again no change was observed at greater distances. At both regional and landscape scale of selection the reindeer avoided the wind farm areas during the construction phase. Third, already existing infrastructure and forest management such as large roads and young forest already had a negative impact on reindeer habitat selection at both the landscape and home range scales of selection both prior to and following development. Hence, while existing development already impacted reindeer use before development, the additional construction activity substantially reduced movement and migration corridors and resulted in apparent holding patterns on either side of previously used corridors.

\section{Changes in use of movement corridors}

Through the BBMM-analysis we identified several important movement corridors over the spine road. These corridors were obviously important for connectivity within these calving/post-calving ranges and were used frequently by the reindeer before development. Both the total area used by the reindeer within the wind farm and the number of passages decreased during the construction phase, at the same time as the reindeer activity (step length) increased. Movement corridors are usually not important as foraging habitats, but vital for the connectivity of the landscape. It is therefore essential to sustain the use of such corridors so as not to loose the functionality of the landscape for the reindeer (Sawyer et al. 2009). These original narrow corridors were already at risk due to the spine road and the nearby settlements, and the construction period of the wind farms and their associated infrastructure may have caused a nearbreakdown in their use, with a significant impact on migrations between the grazing areas across the entire study area (with consequences for the functioning of the ecosystem of the whole reindeer herding community). Thus, the findings in this study of disrupted movement along corridors may be an example of an additional cumulative effect of the construction of wind farms; areas that are already impacted (e.g. by the spine road and forestry) are further affected and reindeer change the use or are hindered from using grazing ranges available previously. Similar declines in the final stages or additional development have also been observed with caribou in relation to progressive oilfield infrastructure (Cameron et al. 1992; Nellemann and Cameron 1998; Joly et al. 2006), hydropower development (Mahoney and Schaefer 2002), and for other ungulates in relation to gas field development (Sawyer et al. 2013).

Construction of wind farms associated with a new road network and power line construction creates a great deal of human and industrial activity in the area. During and just after calving, the females and their calves exhibit increased sensitivity to disturbances. This is not surprising, since the new-born calf is vulnerable and not very mobile, and the mother has to be aware of any stimuli that may signal the presence of predators (Espmark 1971; Skjenneberg and Slagsvold 1979). At the same time, the energy demand associated with lactation is high and the growth of new vegetation has just started in the post-calving period (White 1992). Any disturbance that prevents females from using the available pasture will thus be detrimental. In contrast to these needs we found that female reindeer increased their energy expenditure (step length) at the same time as they reduced their use of these corridors. 
Changes in habitat selection

When the construction started in the previously preferred area around the wind farms the use declined further as confirmed both by the estimates in RSFmodels and the decline in the amount of stopover habitat within the wind farm area. The reindeer's response to construction sites within their grazing ranges is a response commonly found in similar studies of both reindeer and caribou, especially during calving or in late winter (e.g. Anttonen et al. 2011; Leblond et al. 2011; Helle et al. 2012). Colman et al. (2013), studying the effect of a wind farm construction site on reindeer habitat use from June to September, including the main period of insect harassment (i.e. they did not study the calving period) claimed, opposite to our results and former disturbance studies (e.g. Vistnes and Nellemann 2008), that the wind farm construction site was not avoided. This lack of response toward infrastructure and human activity is quite common during insect harassment (e.g. Noel et al. 1998; Skarin et al. 2004), which provides a major stress factor to reindeer, or could even erroneously reflect holding patterns. Furthermore, their study significantly underestimated the importance of scale, studying two peripheral peninsulas of the range, both of which were exposed to different types of development, and using a road section as a control for a wind farm site development. Indeed, most importantly in their study, the majority of the range away from any development seemed to have had a far higher density of animals ( 9 reindeer $/ \mathrm{km}^{2}$ in whole range vs. 0.5-7.3 $(\mu=2.5)$ reindeer $/ \mathrm{km}^{2}$ in the study area), suggesting that avoidance had already taken place in both the experimental and control sites. This is similar to such discrepancies pointed out in other studies that have failed to incorporate the importance of scale (Joly et al. 2006; Vistnes and Nellemann 2008). For example, Vistnes and Nellemann (2008) found in a review that a majority of studies performed within $2 \mathrm{~km}$ from a disturbance source did not find any effect of a disturbance, while a majority of studies performed within distances further away than $2 \mathrm{~km}$ found largescale avoidances of the disturbance source.

Reduced used of corridors and avoidance may also lead to an intensified use of remaining habitat elsewhere (Nellemann et al. 2003; Sawyer et al. 2013). Long-term changes (10-20 years), such as persistent avoidance and lack of migration following development of previously used areas have been found elsewhere in relation to power lines, roads and active tourist trails (Nellemann et al. 2003, 2010). Subsequent removal of the apparent "threat" resulted in almost instantaneous re-use of areas even after more than 10 years of avoidance (Nellemann et al. 2010). Apparent accumulation of reindeer on either side of barriers (in this study mainly seen in the intensified use of the area on eastern side of the spine road) could also lead to faulty conclusions that reindeer did not avoid the development or even increased their use in some circumstances. Reindeer will have a high motivation to access favoured and previously known habitat and to follow traditional or natural migration routes and movement corridors, as has been observed over centuries or even millennia for reindeer and caribou through placement of ancient pit-fall trapping systems in corridors (Panzacchi et al. 2012). Holding patterns of reindeer "accumulating" on either side of barriers reflect reluctance or fear of crossing, not an increased use (cf. Preisler et al. 2006). This must be considered in avoidance studies and also in the further research needed to evaluate the long-term effect of wind farms in operation.

The low use of the high elevation wind farm area (especially around Jokkmokksliden and at the north slope of Storliden, compare Fig. 3), in part, might also be because it represents lower quality foraging habitat and because of its proximity to the spine road and settlements, whereas the low lying areas in the study area are apparently good habitat. The forest at Jokkmokksliden is intensely managed with a high proportion of $P$. contorta and dense young forest, making it less attractive for reindeer (Kumpula et al. 2007), as also noted by the herders (pers. com. Jan Rannerud). P. contorta forms dense forests with little ground vegetation cover and poor regrowth of high quality vegetation. Furthermore, according to the reindeer herders, the reindeer prefer Storliden after calving, during the post-calving period. The preferred heaths and clear cut areas and the scattered forest east of Storliden probably also give the reindeer a better opportunity to scout for predators and escape insects compared to the dense planted forest in Jokkmokksliden. Slightly undulating terrain, open forests and even clear cuts were preferred during this period, probably because of the abundance of forage and more rapid green-up due to the more open and sunny conditions, promoting plant development and an abundance of 
nutritious Eriophorum flowers (Nellemann and Thomsen 1994), as well as dry land for calving.

The existing road network had a clear negative impact on reindeer habitat selection both at the landscape and the home range scale of selection. Even though these roads had existed for a long time in the landscape the reindeer did not seem to have habituated to their presence. Avoidance of roads is commonly found in similar studies of both reindeer and caribou, especially during calving or in late winter (e.g. Lundqvist 2007; Anttonen et al. 2011; Leblond et al. 2011), and they are usually avoided by reindeer with a distance of 1-1.5 km (Skarin and Åhman 2014). Although the mean density of roads was low in the area $\left(0.32 \mathrm{~km} / \mathrm{km}^{2}\right)$, it was never more than $4 \mathrm{~km}$ to the nearest main road. This gave little room for the reindeer to find undisturbed areas, and possibly making the reindeer extra vulnerable towards new developments as they had little chance of finding alternative undisturbed areas.

We found that the reindeer actually preferred the area around the smaller $(30 \mathrm{kV})$ pre-existing power lines. This was also somewhat unexpected, as data from pellet group counts in the same area (Skarin et al. 2013) and other studies of wild reindeer (Nellemann et al. 2003) show that reindeer avoid power lines, albeit lines carrying up to 10 times higher voltage and with much bigger pylons. However, it has recently been discovered that reindeer are the only members of Cervidae who can see UV light (Hogg et al. 2011), which potentially make them very sensitive to the corona produced by power lines (Tyler et al. 2014). If this is the case, we could expect a difference in sensitivity towards power lines during dark winter nights compared to light summer nights with the midnight sun.

\section{Conclusion}

Based on our results, we conclude that even development of smaller wind farms in an already fragmented landscape may influence reindeer habitat and range use, impact the use of movement corridors and cause increased use of surrounding areas. These findings are not only supported in literature from a range of disturbance studies on reindeer and caribou, but also by the observed decreased use of areas near infrastructure during construction, suggesting a causal mechanism. Caution should be exercised when planning wind farms in reindeer habitat, especially in relation to the associated infrastructure.

Acknowledgments This work has been made possible though financing from the Swedish Agency of Energy and the research programme "Vindval", the Reindeer Development Fund in Norway and the project "Vindkraft i reinbetesland". The work of Per Sandström was also partially financed by the Formas project PLURAL. We are also grateful for the contribution from the reindeer herders in Malå reindeer herding community, informing us of reindeer husbandry events and reindeer range use within the reindeer-herding community.

Open Access This article is distributed under the terms of the Creative Commons Attribution 4.0 International License (http:// creativecommons.org/licenses/by/4.0/), which permits unrestricted use, distribution, and reproduction in any medium, provided you give appropriate credit to the original author(s) and the source, provide a link to the Creative Commons license, and indicate if changes were made.

\section{References}

Angrist JD, Pischke JS (2009) Mostly harmless econometrics: an empiricists companion. Princeton University Press, Princeton

Anttonen M, Kumpula J, Colpaert A (2011) Range selection by semi-domesticated reindeer (Rangifer tarandus tarandus) in relation to infrastructure and human activity in the boreal forest environment, northern Finland. Arctic 64:1-14

Bates D, Mächler M, Bolker BM, Walker SC (2014) lme4: linear mixed-effects models using Eigen and S4. J Stat Softw (Submitted). ArXiv E-Print

Boyce MS, Vernier PR, Nielsen SE, Schmiegelow FKA (2002) Evaluating resource selection functions. Ecol Model 157:281-300

Calenge C (2006) The package "adehabitat" for the R software: a tool for the analysis of space and habitat use by animals. Ecol Model 197:516-519. doi:10.1016/J.Ecolmodel.03.017

Cameron RD, Reed DJ, Dau JR, Smith WT (1992) Redistribution of calving caribou in response to oil-field development on the Arctic slope of Alaska. Arctic 45:338-342

Colman JE, Eftest $\varnothing 1$ S, Tsegaye D, Flydal K, Mysterud A (2012) Is a wind-power plant acting as a barrier for reindeer Rangifer tarandus tarandus movements? Wildl Biol 18:439-445. doi:10.2981/11-116

Colman JE, Eftest $\varnothing 1$ S, Tsegaye D, Flydal K, Mysterud A (2013) Summer distribution of semi-domesticated reindeer relative to a new wind-power plant. Eur $\mathrm{J}$ Wildl Res 59:359-370. doi:10.1007/s10344-012-0682-7

Danell Ö (2005) The robustness of reindeer husbandry-need for a new approach to elucidate opportunities and sustainability of the reindeer industry in its socio-ecological context. Rangifer Rep 10:39-49

Espmark Y (1971) Mother-Young relationship and ontogeny of behaviour in reindeer (Rangifer tarandus L.). Z Für Tierpsychol 29:42-81 
Frair JL, Fieberg J, Hebblewhite M, Cagnacci F, DeCesare NJ, Pedrotti L (2010) Resolving issues of imprecise and habitat-biased locations in ecological analyses using GPS telemetry data. Philos Trans R Soc Lond B 365:2187-2200. doi:10.1098/rstb.2010.0084

Gillies CS, Hebblewhite M, Nielsen SE, Krawchuk MA, Aldridge CL, Frair JL, Saher DJ, Stevens CE, Jerde CL (2006) Application of random effects to the study of resource selection by animals. J Anim Ecol 75:887-898. doi:10.1111/j.1365-2656.2006.01106.x

Helle T, Hallikainen V, Sarkela M, Haapalehto M, Niva A, Puoskari J (2012) Effects of a holiday resort on the distribution of semi-domesticated reindeer. Ann Zool Fenn 49:23-35

Hogg C, Neveu M, Stokkan K-A, Folkow L, Cottrill P, Douglas R, Hunt DM, Jeffery G (2011) Arctic reindeer extend their visual range into the ultraviolet. $J$ Exp Biol 214:2014-2019. doi:10.1242/jeb.053553

Horne JS, Garton EO, Krone SM, Lewis JS (2007) Analyzing animal movements using Brownian bridges. Ecology 88:2354-2363

Johnson DH (1980) The comparison of usage and availability measurements for evaluating resource preference. Ecology 6:65-71

Joly K, Nellemann C, Vistnes I (2006) A reevaluation of caribou distribution near an oilfield road on Alaska's North Slope. Wildl Soc Bull 34:866-869. doi:10.2193/0091-7648

Klein DR (1971) Reaction of reindeer to obstructions and disturbances. Science 173:393-398. doi:10.1126/Science. 173.3995 .393

Kumpula J, Colpaert A, Anttonen M (2007) Does forest harvesting and linear infrastructure change the usability value of pastureland for semi-domesticated reindeer (Rangifer tarandus tarandus)? Ann Zool Fenn 44:161-178

Leblond M, Frair J, Fortin D, Dussault C, Ouellet JP, Courtois R (2011) Assessing the influence of resource covariates at multiple spatial scales: an application to forest-dwelling caribou faced with intensive human activity. Landscape Ecol 26:1433-1446. doi:10.1007/S10980-011-9647-6

Lundqvist H (2007) Ecological cost-benefit modelling of herbivore habitat quality degradation due to range fragmentation. Trans GIS 11:745-763. doi:10.1111/j.1467-9671. 2007.01070.x

Mahoney SP, Schaefer JA (2002) Hydroelectric development and the disruption of migration in caribou. Biol Conserv 107:147-153

Manly BFJ, McDonald LL, McDonald TL, Erickson WP (2002) Resource selection by animals, 2nd edn. Kluwer Academic Publishers, Dordrecht

Nellemann C, Cameron RD (1998) Cumulative impacts of an evolving oil-field complex on the distribution of calving caribou. Can J Zool 76:1425-1430

Nellemann C, Thomsen MG (1994) Terrain ruggedness and caribou forage availability during snowmelt on the Arctic Coastal-Plain, Alaska. Arctic 47:361-367

Nellemann C, Vistnes I, Jordhoy P, Strand O (2001) Winter distribution of wild reindeer in relation to power lines, roads and resorts. Biol Conserv 101:351-360

Nellemann C, Vistnes I, Jordhoy P, Strand O, Newton A (2003) Progressive impact of piecemeal infrastructure development on wild reindeer. Biol Conserv 113:307-317
Nellemann C, Vistnes I, Jordhoy P, Stoen OG, Kaltenborn BP, Hanssen F, Helgesen R (2010) Effects of recreational cabins, trails and their removal for restoration of reindeer winter ranges. Restor Ecol 18:873-881. doi:10.1111/j. 1526-100X.2009.00517.x

Noel LE, Pollard RH, Ballard WB, Cronin MA (1998) Activity and use of active gravel pads and tundra by Caribou, Rangifer tarandus granti, within the Prudhoe Bay oil field, Alaska. Can Field-Nat 112:400-409

Össbo ̊̊, Lantto P (2011) Colonial tutelage and industrial colonialism. Reindeer husbandry and early 20th-century hydroelectric development in Sweden. Scand J Hist 36:324-348. doi:10.1080/03468755.2011.580077

Panzacchi M, Van Moorter B, Jordhoy P, Strand O (2012) Learning from the past to predict the future: using archaeological findings and GPS data to quantify reindeer sensitivity to anthropogenic disturbance in Norway. Landscape Ecol. doi:10.1007/s10980-012-9793-5

Pape R, Loeffler J (2012) Climate change, land use conflicts, predation and ecological degradation as challenges for reindeer husbandry in Northern Europe: what do we really know after half a century of research? Ambio 41:421-434. doi:10.1007/s13280-012-0257-6

Polfus JL, Hebblewhite M, Heinemeyer K (2011) Identifying indirect habitat loss and avoidance of human infrastructure by northern mountain woodland caribou. Biol Conserv 144:2637-2646. doi:10.1016/j.biocon.2011.07.023

Preisler HK, Ager AA, Wisdom MJ (2006) Statistical methods for analysing responses of wildlife to human disturbance. J Appl Ecol 43:164-172

R Core Team (2015) R: a language and environment for statistical computing. R Foundation for Statistical Computing, Vienna. URL http://www.R-project.org/

Reese H, Nilsson M, Pahlén TG, Hagner O, Joyce S, Tingelöf U, Egberth M, Olsson H (2003) Countrywide estimates of forest variables using satellite data and field data from the national forest inventory. Ambio 32:542-548. doi:10.1579/ 0044-7447-32.8.542

Riksdagen (2009) Betänkande 2008/09:NU25 Riktlinjer för energipolitiken. Betänkande näringsutskottet, Swedish Parliament, Stockholm. (In Swedish)

Sametinget, Markanvändning rennäring (In Swedish). Available from http://sametinget.se/8796. Accessed Mar 2015

Sappington JM, Longshore KM, Thompson DB (2007) Quantifying landscape ruggedness for animal habitat analysis: a case study using bighorn sheep in the Mojave Desert. J Wildl Manag 71:1419-1426. doi:10.2193/2005-723

Sawyer H, Kauffman MJ, Nielson RM, Horne JS (2009) Identifying and prioritizing ungulate migration routes for landscape-level conservation. Ecol Appl 19:20162025

Sawyer H, Kauffman MJ, Middleton AD, Morrison TA, Nielson RM, Wyckoff TB (2013) A framework for understanding semi-permeable barrier effects on migratory ungulates. J Appl Ecol 50:68-78. doi:10.1111/1365-2664.12013

Skarin A, Åhman B (2014) Do human activity and infrastructure disturb domesticated reindeer? The need for the reindeer's perspective. Polar Biol. doi:10.1007/s00300-014-1499-5

Skarin A, Danell Ö, Bergstrom R, Moen J (2004) Insect avoidance may override human disturbances in reindeer habitat selection. Rangifer 24:95-103 
Skarin A, Nellemann C, Sandström P, Rönnegård L, Lundqvist H (2013) Renar och vindkraft. Studie från anläggningen av två vindkraftparker i Malå sameby. Naturvårdsverket/ Swedish Environmental Protection Agency, Bromma

Skjenneberg S, Slagsvold L (1979) Reindeer husbandry and its ecological principles (Translated from Norwegian "Reindriften og dens naturgrunnlag" 1968). U.S. Department of the Interior Bureau of Indian Affairs, Juneau

Tyler N, Stokkan K-A, Hogg C, Folkow L, Cottrill P, Douglas R, Hunt DM, Jeffery G (2014) Ultraviolet vision and avoidance of power lines in birds and mammals. Conserv Biol 28:630-631. doi:10.1111/cobi.12262
Vistnes I, Nellemann C (2001) Avoidance of cabins, roads, and power lines by reindeer during calving. J Wildl Manag 65:915-925

Vistnes I, Nellemann C (2008) The matter of spatial and temporal scales: a review of reindeer and caribou response to human activity. Polar Biol 31:399-407

White RG (1992) Nutrition in relation to season, lactation, and growth of north temperate deer. In: Brown RD (ed) The biology of deer. Springer, New York, pp 407-417

Zuur AF, Ieno EN, Walker NJ, Saveliev AA, Smith GM (2009) Mixed effects models and extensions in ecology with R. Springer, Berlin 